\title{
CORRIGENDUM
}

\section{Intake of fruit and vegetables: implications for bone health}

\author{
By Susan A. New \\ Volume 62 (2003), Number 4
}

Fig. 3 legend

For:

Fig. 3. Long-term ingestion of ammonium chloride $(2 \mathrm{~g} / \mathrm{l})$ caused a decrease in bone characteristics and the development of

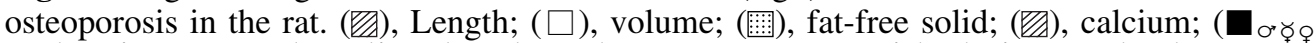

), density; (---), baseline level. Values are means with their standard errors repre-

Read:

Fig. 3. Long-term ingestion of ammonium chloride $(2 \mathrm{~g} / \mathrm{l})$ caused a decrease in bone characteristics and the development of

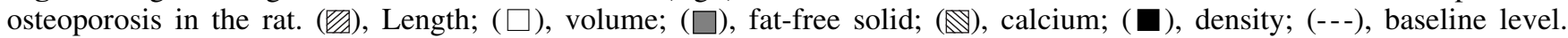
Values are means with their standard errors represented by vertical bars. (From Barzel, 1969.) 